$10-10-2007$

\title{
Hearsay Law: Recent Developments in Maryland and in the Supreme Court
}

Lynn McLain

University of Baltimore, Imclain@ubalt.edu

Follow this and additional works at: http://scholarworks.law.ubalt.edu/all_fac

Part of the Evidence Commons

\section{Recommended Citation}

Lynn McLain, Hearsay Law: Recent Developments in Maryland and in the Supreme Court, (2007).

Available at: http://scholarworks.law.ubalt.edu/all_fac/926

This Conference Proceeding is brought to you for free and open access by the Faculty Scholarship at ScholarWorks@University of Baltimore School of Law. It has been accepted for inclusion in All Faculty Scholarship by an authorized administrator of ScholarWorks@University of Baltimore School of Law. For more information, please contact snolan@ubalt.edu. 


\section{Hearsay Law: Recent Developments \\ in Maryland and in the Supreme Court \\ Anne Arundel County Bar Association CLE \\ Wednesday, October 10, 2007 \\ 5:30-7:30 p.m. \\ Professor Lynn McLain \\ University of Baltimore School of Law}

\section{$\underline{\text { Contents }}$}

$\underline{\text { Page }}$

\section{Hearsay Law: Both Civil and Criminal Cases}

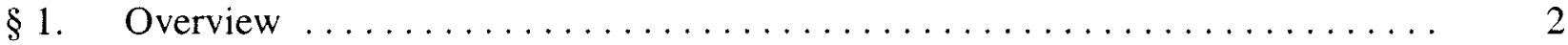

§ 2. Generally, Evidence Not Offered as Substantive Evidence

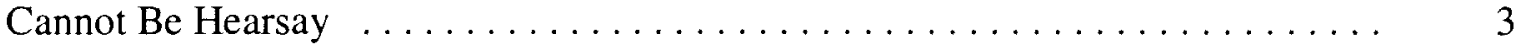

§3. The Two Elements of "Out-of-Court" "Statement" ............... 3

$\S 4$. Making and Meeting Hearsay Objections $\ldots \ldots \ldots \ldots \ldots \ldots \ldots$

$\S 5 . \quad$ "TOMA"? or Nonhearsay? $\ldots \ldots \ldots \ldots \ldots \ldots \ldots \ldots \ldots \ldots \ldots \ldots \ldots$

$\S 6 . \quad$ Important Recent Maryland Decisions: Implied Assertions $\ldots \ldots \ldots \ldots \ldots \ldots$

\$ 7. Specific Exceptions $\ldots \ldots \ldots \ldots \ldots \ldots \ldots \ldots \ldots \ldots \ldots \ldots \ldots \ldots \ldots \ldots$

II. The Confrontation Right after Crawford v. Washington: Criminal Cases

$\S 1$ Texts of the U.S. and Maryland Clauses; Citations to U.S. Supreme Court and Maryland Court of Appeals Cases $\ldots \ldots \ldots \ldots \ldots \ldots \ldots \ldots$

$\S 2$ When Does the Clause Apply? $\ldots \ldots \ldots \ldots \ldots \ldots \ldots \ldots \ldots \ldots \ldots \ldots \ldots$

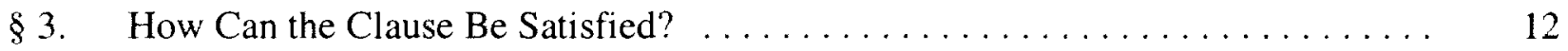

$\S 4$. How Does the Confrontation Clause Relate to the Hearsay Rule? . . . . . . . 12

$\S 5 . \quad$ What If the Hearsay Evidence is Nontestimonial? $\ldots \ldots \ldots \ldots \ldots \ldots \ldots \ldots \ldots$ 
$\S 6$. What Did Crawford and Davis Hold as to Whether a Statement is

Testimonial or Nontestimonial? . . . . . . . . . . . . . . . . . . . . .

§7. How Can We Analyze Whether Statements Outside the Holdings of

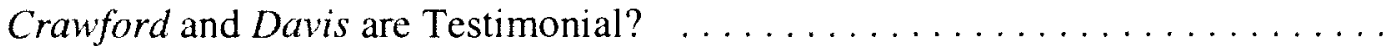

§ 8. How Did the Maryland Court of Appeals Interpret Crawford in

Snowden?

§ 9. What About "Business Records" of the State? .................... 20

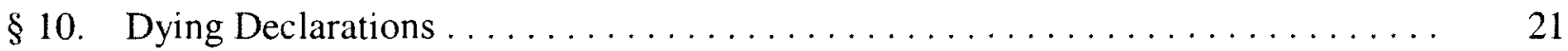

$\S 11$. How Are Prosecutors and Domestic Violence Victim-Advocates

Likely to Adapt to these Changes? . . . . . . . . . . . . . . . . . . . . . 2

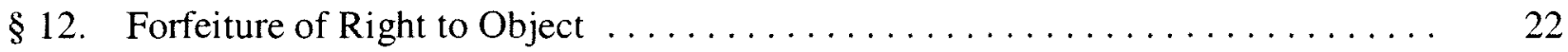

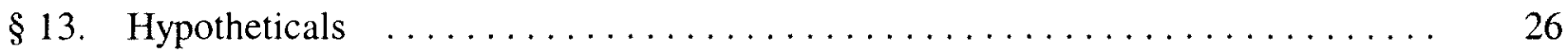

I. Hearsay Law: Both Civil and Criminal Cases

\section{§1. Overview}

To apply the exclusionary hearsay rule, one must make two determinations:

(1) Is the proffered evidence hearsay (Rule 5-801)? If the evidence is nonhearsay, the hearsay rule will not exclude it (though it may be excluded by other rules, such as Rule 5-403, other relevance rules, or privileges).

The second question must be answered only if the evidence is hearsay:

(2) If it is hearsay, is it nonetheless not excluded by the hearsay rule, because it falls within an exception to that rule (Rules 5-803 and 5$804)$ ?

If it is hearsay but neither the hearsay rule nor other rules of evidence exclude it, then one must ask whether the Constitution excludes the evidence: 
If it is offered against a criminal accused, and it does fall within a hearsay exception, does its admission comply with the confrontation clause (see II.)? See, e.g., Tennessee v. State, 471 U.S. 409 (1985) (defendant's rights under the Confrontation Clause were not violated by the introduction of the confession of an accomplice for the nonhearsay purpose of rebutting respondent's testimony that his own confession was coercively derived from the accomplice's statement).

(4) If it is offered in any proceeding to which the due process clause applies, is it reliable hearsay?

Evidence is hearsay if (1) an out-of-court statement of a person ("OCS") is being proved, and (2) in order for that OCS to help to prove the fact it is being offered to prove today at trial, the fact-finder would have to assume that the out-of-court speaker or writer (the "declarant") believed a particular fact to be true and that the declarant was correct, i.e., that fact was true. The shorthand for this last element is that the OCS is offered now to prove the truth of some matter that was (explicitly or implicitly) asserted by the declarant when the declarant made the statement ("TOMA"): OCS + TOMA = Hearsay.

\section{§ 2. Generally, Evidence Not Offered as Substantive Evidence Cannot Be Hearsay}

Because of the TOMA element, only substantive evidence can be hearsay. Evidence of a declarant's statement offered only to impeach that declarant, or for purposes of his or her credibility only, cannot be hearsay.

Usually, such non-substantive evidence would be a declarant's prior inconsistent statement, offered under Rule 5-613, rather than as substantive evidence under Rule 5-802.1(a). It also would include a prior consistent statement, offered to rehabilitate the declarant's credibility under Rule 5-616, rather than as substantive evidence under Rule 5-802.1(b). The hearsay rule does not permit impeaching one person by another person's OCS (unless there is an agency relationship between the two). E.g., U.S. v. Libby, 475 F.Supp.2d 73, 77 (D.D.C. 2007).

Similarly, if experts in a particular field reasonably rely on certain types of hearsay in reaching their opinions, Rule 5-703 provides that the court has discretion to admit that otherwise inadmissible hearsay basis, for the limited nonsubstantive purpose of explaining how the expert arrived at the opinion.

\section{§. The Two Elements of "Out-of-Court" "Statement"}

Rule 5-801(c) defines OCS as "a statement, other than one made by the declarant while testifying at the trial or hearing. ..." Rule 5-801(a) defines a "statement" as "(1) an oral or written assertion or (2) nonverbal conduct of a person, if it is intended by the 
person as an assertion." It can be fairly said, then, that a "statement" is an assertion of fact(s) by a person.

Because of the first part of the definition in Rule 5-801(c), for purposes of the rules of evidence even the prior statement of a witness who is testifying today at trial is considered an OCS. Thus the hearsay rule excludes a witness's own prior statements unless either (1) they are offered only for a relevant nonhearsay purpose or (2) the proper foundation has been laid to support a finding by the trial judge that they fall within a particular hearsay exception (or exceptions). This may be surprising, because, after all, this witness declarant can be crossexamined at trial. Thus, this preference for live memory is reflected only in a rule of evidence, and not in the confrontation clause.

\section{Problems.}

\section{Does "statement" in Rule 5-801(a) include:}

a. A parrot's exclamation, when the police entered the apartment to find the dead body of Jennifer, the owner of the parrot, "Richard stabbed me! Richard stabbed me!"

b. A hand-stamped "Received April 12, 2003" on a document?

c. A gas and electric bill, stating that the homeowner owed $\$ 310.06$ for July 2007 ?

d. Does "statement" include the mass-printed writing on a cocktail napkin, "Bohager's, Fells Point, Baltimore"?

In each case, whom would you want to cross examine? See United States $v$. Washington, F.3d __, 2007 WL 2378024 (4th Cir., Aug. 22, 2007) (data generated by Armed Forces forensic lab's diagnostic machines regarding alcohol and drugs in defendant's blood were not statements of a person) (2-to-1 decision).

\section{§. Making and Meeting Hearsay Objections}

A. If a hearsay objection is properly made because the evidence includes an OCS, the proponent of the evidence must meet the objection by explaining to the court how either the evidence is nonhearsay or it falls within a hearsay exception. Otherwise, the court may correctly sustain the objection.

B. Timeliness. You can object in anticipation - but if your objection is overruled when it is premature (before the hearsay itself is asked for), repeat it when ripe, so as not to be held to have waived it. 


\section{§. "TOMA"? or Nonhearsay?}

Remember, an OCS is not hearsay if it is probative of and offered to prove a RELEVANT fact other than "TOMA" (the truth of any fact asserted by the declarant when the declarant made the OCS). All evidence must comply with Rule 5-402, requiring relevance. Offering evidence for a nonhearsay purpose that is not relevant will not provide a route around the hearsay rule. E.g., Boyd v. State, 399 Md. 457, 924 A.2d 1112 (2007).

An easy way to look at the TOMA element is to ask, "Even if the out-of-court declarant was factually incorrect with regard to the assertion s/he made in the OCS, is it still relevant that the declarant made the statement?" "Is it relevant simply that the OCS was made?" If the answer to either of these questions is yes, the evidence is NONHEARSAY. (A limiting instruction under Rule 5-105 may be appropriate.)

Another way of looking at this process is as a bus ride; you jump off the bus as soon as you get some probative value as to the fact the OCS is offered to prove.

\begin{tabular}{|l|l|l|}
\hline \multicolumn{1}{|c|}{ Metrobus } & \multicolumn{1}{|c|}{ Metrobus } \\
$\begin{array}{l}\text { If it doesn't matter whether } \\
\text { Decl.. believed what s/he said } \\
\text { or not, EVI. is probative } \\
\text { anyway, merely because OCS } \\
\text { was made: }\end{array}$ & $\begin{array}{l}\text { If EVI. will help to prove fact } \\
\text { it's offered to prove, as long as } \\
\text { Decl. believed what s/he said, } \\
\text { even if Decl. was factually } \\
\text { wrong. }\end{array}$ & $\begin{array}{l}\text { Metrobus } \\
\text { If Decl.'s belief alone is } \\
\text { insufficient: we need for } \\
\text { Decl. to have been both } \\
\text { sincere and factually correct, } \\
\text { in order for fact-finder to } \\
\text { properly rely on the Evi. to } \\
\text { help to prove the Material } \\
\text { Fact. }\end{array}$ \\
$\begin{array}{l}\text { Get off at } \\
\text { BUS STOP \#1: Nonhearsay } \\
\text { (Types a, b, or c below) }\end{array}$ & $\begin{array}{l}\text { Get off at } \\
\text { BUS STOP \# 2: Nonhearsay } \\
\text { (Type d below) }\end{array}$ & $\begin{array}{l}\text { Ride all the way to } \\
\text { TERMINUS: Hearsay }\end{array}$ \\
\hline
\end{tabular}

\section{Problems.}

Witness is called to testify: "The shopkeeper told me one of the people who robbed her was Wally." Is this evidence hearsay (an OCS + TOMA) if it is offered to prove the following?

1. Wally robbed the shopkeeper.

2. The witness knows the shopkeeper.

3. The shopkeeper was alive on the day she spoke to the witness. 
4. Wally is a criminal.

5. The shopkeeper and the witness were "on speaking terms."

6. Wally was in the town where the shop is on the day of the robbery.

Analysis: For example, would the fact that the shopkeeper said to the witness, that "Wally was one of the robbers" help to prove that Wally was in that town on the day of the robbery only if the shopkeeper was factually correct about one or more of the facts she asserted in the OCS?

Four categories of OCS's that are NONHEARSAY because they are offered for a purpose other than to prove TOMA [both belief and accuracy of the declarant as to something s/he was asserting at the time the declarant made the OCS] come up repeatedly:

a. "LEGALLY OPERATIVE FACTS" (Verbal acts or Verbal Parts of Acts)

1. VERBAL ACTS (here, generally, the substantive law regarding the particular type of claim or defense requires that an out-of-court statement have been made in order for the type of claim, charge, or defense to exist), e.g., contracts; wills; the alleged defamatory statement. You cannot have a contract, for example, without an offer and an acceptance. The utterance of the statement(s) creates the claim, etc.

Example: Mario sues D for slander. Mario calls W to testify that D said to W, "Mario is a liar and a cheat." Mario simply wants to prove that D made the OCS (published it to a third person) - certainly not to prove that what D said was true. $\mathrm{D}$ has to have made such a type of statement in order for Mario to prove the element of publication.

2. VERBAL PARTS OF ACTS (giving a particular legal effect, by virtue of the substantive law, to an otherwise legally ambiguous nonverbal act). These OCS's have probative value under the substantive law, regardless of the declarant's sincerity (truthfulness). For example, the statement, "This is a gift," when handing over a ring, makes it a donative transfer, even if the declarant was intending to steal the ring back later. Similarly, a threatening statement accompanying an otherwise ambiguous act can make the combination an assault.

b. STATEMENTS OFFERED TO PROVE THEIR EFFECT ON THEIR HEARER OR READER

These statements, e.g., statements putting the hearer or reader on notice ("Caution: Wet Floor") or statements affecting the reasonableness of the hearer's or 
reader's subsequent conduct ("Don't touch that, it's hot!") are probative for that purpose, regardless of either the declarant's sincerity or accuracy.

- If A testifies that she heard B tell the store manager, 15 minutes before a slip and fall, that "There's a spill in Aisle 6," can this evidence be relevant for a nonhearsay purpose? How? Note that, if offered for a nonhearsay purpose, it may not be used as substantive evidence that there was a spill in Aisle 6. A limiting instruction under Rule 5-105 may be requested.

See, e.g., Shipp v. United States, 212 Fed. Appx. 393 (6th Cir. 2006) (unpublished) (malicious prosecution case).

\section{c. STATEMENTS OFFERED AS CIRCUMSTANTIAL EVIDENCE OF THE DECLARANT'S CONSCIOUSNESS, ABILITY TO TALK, ABILITY TO SPEAK A PARTICULAR LANGUAGE, ETC.}

- Neither sincere belief nor accuracy of the declarant is needed for this category of non-hearsay. For example, consider the statement of a person (not the Prince of Wales) trapped in a car, "I am Charles, Prince of Wales," offered to show consciousness, which is relevant to conscious pain and suffering, which is relevant to damages. It does not matter whether what the declarant said was true, simply that she said something.

\section{d. STATEMENTS OFFERED AS CIRCUMSTANTIAL -- NOT DIRECT -- EVIDENCE OF THE DECLARANT'S EMOTION, STATE OF MIND, KNOWLEDGE, BELIEF, INTENT, SANITY OR INSANITY}

In this final one of the "big four" categories of nonhearsay, the relevance requirement is met if the declarant was sincere, regardless of the declarant's accuracy as to the facts asserted by him or her. E.g., in A's trial for murder of B, the State calls C to testify to A's OCS one week before the murder, "B is not only mean and nasty, he's an [expletive deleted]." To be relevant to the State's case, it does not matter whether B was really mean, nasty, etc. Therefore, it is nonhearsay, as we care only that apparently A believed that B was nasty, not whether $\mathbf{A}$ was correct as to the fact A asserted, that B was nasty.

See, e.g., Thomas v. State, 397 Md. 557, 575-80, 919 A.2d 49 (2007) (evidence of defendant's initial refusal to provide a blood sample was properly admitted as circumstantial evidence of consciousness of guilt as State had laid proper foundation by showing that defendant was told blood was needed in reference to victim's death); Holland v. State, $122 \mathrm{Md}$. App. 532, 713 A.2d 364 (1998) (witness testified defendant or one of his companions in motel room said "We're going down the strip to sell"; Judge Moylan explains: "The words were offered as circumstantial evidence that either the appellant or the other codefendant who uttered them along with others who heard the words were privy to a concerted plan to sell narcotics-on the strip or 
elsewhere, immediately or after the coast was clear. The very uttering of the words helped to show the state of mind of the one who uttered them and/or of others who heard them. As circumstantial evidence used to prove that collective state of mind, to wit, the [charged] conspiracy [to sell illegal drugs], the words were non-hearsay."

\section{§ 6. Important Recent Maryland Decisions: Implied Assertions}

The common law rule of Wright $v$. Tatham, an 18th century English case, as to verbal utterances may be stated as follows:

\section{Verbal utterances are hearsay if offered to prove the truth of the matter that was directly asserted by the declarant. They are also hearsay if they are offered to prove the truth of an assertion implied by the declarant, i.e., their proponent is asking the fact-finder to infer that the declarant would not have made the utterance unless he or she believed a particular fact to be true, and the out-of-court utterance is offered to prove the truth of that fact the declarant apparently believed.}

In Stoddard v. State, 389 Md. 681, 887 A.2d 564 (2005), the Court of Appeals of Maryland (4to-3) adopted this approach. There the OCS was of an 18-month-old child who said to her mother, "Is [the defendant] going to get me?" The evidence was relevant only if offered to prove that the child had seen the defendant "get" the murder victim.

Under this approach, each of the following is an OCS + TOMA:

\section{Evidence}

a. D said, "Do you need change?"

b. D said, "Carlos, do you have the stuff?"

c. D, a burglar, said, "Ernie, come in here."

d. D said to $X$, "You wouldn't want anything to happen to your pretty wife."

e. $\quad$ D asked $X$, "When are you going to pay me back my money?"

f. D said to $X$, his alleged coconspirator, "Nice to meet you."
Offered to Prove

$\mathrm{D}$ had access to change.

Carlos dealt drugs.

Ernie was there and was D's accomplice.

$\mathrm{D}$ was threatening $\mathrm{X}$.

$X$ had borrowed money from $D$.

$\mathrm{D}$ had never met $\mathrm{X}$ before. 
Contrast:

\section{$\underline{\text { Evidence }}$}

D said, "Does your boss have a burglar alarm?"
Offered to Prove

D was planning a burglary of the premises and committed it and accompanying murder of the store owner.

Here D's intent is relevant. The evidence is relevant in D's subsequent burglary/murder trial as circumstantial evidence of D's state of mind/intent; one "gets off the bus" before reaching any implicit assertion about whether or not there is a burglar alarm. See Carlton $v$. State, 111 Md. App. 436, 681 A.2d 1181 (1996) (finding no intended assertion).

In Bernadyn v. State, 390 Md. 1, 887 A.2d 602 (2005), the Stoddard majority held that a medical bill seized by police at 2024 Morgan Street in Edgewood, Maryland, and addressed to "Michael Bernadyn, 2024 Morgan Street, Edgewood, Maryland 21040," was inadmissible hearsay when used by the State to establish that Bernadyn lived at that address.

- When that scenario recurs, can the foundation for the bill as a business record be laid as to the patient's address? Is there a double hearsay problem?

- Or is the bill with that name on it relevant (does it have probative value connecting Bernadyn to that address) simply because it was found at that address? (See Judge Wilner's dissent.) Consider if, instead, the bill had been found at a garbage dump-then what would the analysis be?

- If the State offers the bill, at retrial, only as circumstantial evidence linking someone using that name with the address where it was found, will it be admissible for that limited purpose? See Fields v. State, 395 Md. 758, 912 A.2d 637 (2006) (declining to reach the issue because error, if any, was harmless) (see also D. Eyler's opinion for majority of the CSA panel, 168 Md. App. 22, 895 A.2d 339 (2006)); Cooley v. State, 157 Md. App. 101, 116, 849 A.2d 1026 (2004), rev'd on other grounds, 385 Md. 165, 867 A.2d 1065 (2005) ("The State's case included testimony that, when the search warrant was executed about 6:20 a.m. on July 20,2001, both Jones and Cooley were present, along with their child. Cooley was sleeping when the police arrived. Both Cooley and Jones were in the bedroom at the time the bullet cartridges were recovered. In addition, paperwork in the names of both Jones and Cooley was recovered from the premises. This evidence was sufficient to establish that Cooley and Jones were residing together at $2001 \mathrm{McCullough}$ Street when the search warrant was executed."). 


\section{§7. Specific Exceptions}

- Rule 5-802.1(a): Certain Prior Inconsistent Statements

To clarify that the declarant's adoption by signature will suffice, and that the declarant need not have been the one to reduce the statement to writing, Md. Rule 5-802.1(a)(2) was amended by order of November 8, 2005, effective January 1, 2006, to read: "A statement that is inconsistent with the declarant's testimony if the statement was ... (2) reduced to writing and was signed by the declarant. ..."

- Rule 5-802.1(c): Prior Statements of Identification

See Jones v. State, 395 Md. 97, 909 A.2d 650 (2006) (reversible error to preclude defense from calling detective who presented photo array to testify at suppression hearing).

- Rule 5-803(b)(3): Direct Assertion of Declarant's State of Mind

See Figgins v. Cochrane, 174 Md. App. 1, 27-31, 920 A.2d 572 (2007) (Hillmon analysis inapplicable when no contention that declarant subsequently acted in accord with stated intent).

- Rule 5-803(b)(4): Statements Made When Seeking Medical Treatment

\section{Sufficiency of Foundation}

In Coates v. State, 2007 WL 2459114, Sept. Term (Md. App., Aug. 31, 2007), statements of an almost 8-year-old to a SAFE pediatric nurse practitioner, regarding sexual abuse occurring over a year earlier, were admitted by the trial court as substantive evidence under Md. Rule 5-803(b)(4). The Court of Special Appeals reversed the resulting conviction, holding that there was inadequate evidence to support a finding that the child "understood that she was being seen for medical treatment or diagnosis." Although the nurse ordered testing for HIV, there was "no indication that [the child] had any understanding ..., that she was at continued risk of developing a latent, sexually transmitted disease or HIV."

\section{Identity of Assailant}

The Coates panel held that the child's identification of the alleged child abuser was not admissible under 5-803(b)(4), because the State knew that the defendant no longer had any contact with the child; thus "this was not a case in which there was a concern as to the identity of the perpetrator in order to prevent continued exposure of the child to the abuser." 
- Rule 5-803(b)(6): Business Records

Hall v. University of Maryland Medical Sys. Corp., 398 Md. 67, 919 A.2d 1177 (2007) (reversible error to exclude statements written by doctors, reporting what nurses and residents had said, regarding pathologically germane information).

- Rule 5-805: Multiple Levels of OCS's Within One OCS

See Cooley v. State, 157 Md. App. 101, 111, 849 A.2d 1026 (2004), rev'd on other grounds, $385 \mathrm{Md}$. 165, $867 \mathrm{~A} .2 \mathrm{~d} 1065$ (2005) (one level of OCS was nonhearsay and the other was hearsay falling within an exception).

\section{The Confrontation Right after Crawford $v$. Washington: Criminal Cases}

\section{§ 1. Texts of the U.S. and Maryland Clauses; Citations to U.S. Supreme Court and Maryland Court of Appeals Cases}

U.S. Const., amend. VI (applicable in federal courts and, via amend. XIV, in state courts): "In all criminal prosecutions, the accused shall enjoy the right . . . to be confronted with the witnesses against him."

MD Declaration of Rights, art. 21: "In all criminal prosecutions every man hath a right ... to be confronted with the witnesses against him, ... to examine the witnesses for and against him on oath."

Maryland state courts construe the two in pari materia (in like matter, in equal fashion). Thus, U.S. Supreme Court decisions apply in Maryland as to both provisions.

See: $\quad$ Crawford v. Washington, 541 U.S. 36, 124 S.Ct. 1354 (2004)

Davis v. Washington, 126 S.Ct. 2266 (2006)

Snowden v. State, 385 Md. 164, 867 A.2d 314 (2005)

Rollins v. State, 392 Md. 435, 397 A.2d 821 (2006)

(For detailed discussions of these and cases from other jurisdictions, see the 2007 pocket part to LYNN MCLAIN, MARYLAND EvidENCE: STATE AND FEDERAL, vol. 6A, §§ 801:1 et seq. (available for purchase at Thomson/West 1-800-344-5009.)

\section{§ 2. When Does the Clause Apply?}

The confrontation clause applies only:

(1) in criminal cases; and only

(2) to "testimonial" hearsay evidence; and only if such evidence is 
(3) offered by the prosecution, against an accused; and only if offered

(4) in a trial on the merits of guilt or innocence.

\section{§3. How Can the Clause Be Satisfied?}

(1) The out-of-court declarant who made the hearsay statement (a) testifies at the trial and (b) the accused has an opportunity to cross-examine the declarant at trial (Crawford (fn. 9); Lawson v. State, 389 Md. 570, 587-89, 886 A.2d 876 (2005));

or (2) The declarant is unavailable to testify at trial (see Fed. R. Evid. 804(a) or Md. Rule 5-804(a)) and the accused has earlier had an opportunity to cross-examine the declarant about his or her statement that is now being offered into evidence;

or (3) The accused has either waived or forfeited his or her confrontation right by either (a) failing to object, citing the confrontation clause; or (b) engaging in wrongdoing (directly or in a conspiracy) that caused the declarant to be unavailable to testify at the trial.

\section{§ 4. How Does the Confrontation Clause Relate to the Hearsay Rule?}

(1) The confrontation clause applies only if the evidence offered is hearsay (an out-of-court statement offered to prove the truth of some fact that was asserted by the out-of-court declarant when the declarant made the prior statement) (Crawford fn. 9) and then only if it is a certain type of hearsay: "testimonial" (i.e., in the nature of testimony and thus considered to be the statement of a "witness" within the meaning of the confrontation clause).

(2) Thus, the first question is whether the evidence is hearsay. If it is, the next question is whether the jurisdiction's rules of evidence (Md. Rules, title 5 or Fed. $R$. Evid.) exclude the evidence. This is a very separate question from whether the confrontation clause excludes it. For one thing, evidence may be hearsay even if the out-of-court declarant testifies to her own out-of-court statement at trial.

(3) If the evidence rules do not exclude the evidence, the next question is whether the confrontation clause excludes it (see $\S 2$ ).

\section{§5. What If the Hearsay Evidence is Nontestimonial?}

If the hearsay statement is "nontestimonial," the confrontation clause does not apply to its admission. Davis $v$. Washington. The only constitutional check will be the due process clause, under which a verdict that was based on unreliable hearsay would be constitutionally unsound. 
As to what is "reliable" we can still look to Ohio v. Roberts, 448 U.S. 56 (1980), for this due process purpose.

\section{§ 6. What Did Crawford and Davis Hold as to Whether a Statement is Testimonial or Nontestimonial?}

Crawford finds the Sixth Amendment unclear on its face and therefore looks to the founders' intent when the Amendment was ratified in 1791. Justice Scalia, writing for the Court, concludes that the founders were concerned that we not repeat a practice that had occurred during "Bloody Mary's" reign in England where - following the civil law practice rather than the common law's approach - justices of the peace gathered ex parte statements from witnesses and later these were offered into evidence at some trials, without the accused being given a chance to cross-examine the makers of the statements.

Justice Scalia remarks, "The involvement of government officers in the production of testimonial evidence presents the same risk, whether the officers are police or justices of the peace." He reasons that "witnesses are those who bear testimony," but declines to articulate a definition of "testimonial." Crawford explicitly states that the following are testimonial under any definition:

(1) "ex parte testimony at a preliminary hearing";

(2) "plea allocution";

(3) "grand jury testimony";

(4) prior trial testimony; and

(5) "[s]tatements taken by police officers in the course of interrogations. ..."

In Davis, again in an opinion authored by Justice Scalia, the Court holds:

Without attempting to produce an exhaustive classification of all conceivable statements - or even all conceivable statements in response to police interrogation - as either testimonial or nontestimonial, it suffices to decide the

1 The Crawford Court explained in its footnote 4 that it declined to define interrogation:

We use the term "interrogation" in its colloquial, rather than any technical legal, sense. Cf. Rhode Island v. Innis, 446 U.S. 291, 300-301, 100 S.Ct. 1682, 64 L.\$Ed.2d 297 (1980). Just as various definitions of "testimonial" exist, one can imagine various definitions of "interrogation," and we need not select among them in this case. Sylvia's recorded statement, knowingly given in response to structured police questioning, qualifies under any conceivable definition.

In footnote 1 in Davis, the Court qualified its reference to interrogation as follows: "This is not to imply, however, that statements made in the absence of any interrogation are necessarily nontestimonial. The Framers were no more willing to exempt from cross-examination volunteered testimony or answers to open-ended questions than they were to exempt answers to detailed interrogation." 
present cases to hold as follows: Statements are nontestimonial when made in the course of police interrogation under circumstances objectively indicating that the primary purpose of the interrogation is to enable police assistance to meet an ongoing emergency. They are testimonial when the circumstances objectively indicate that there is no such ongoing emergency, and that the primary purpose of the interrogation is to establish or prove past events potentially relevant to later criminal prosecution.

Davis involved two cases. In Davis itself, the Court held that the victim's statements during the beginning moments of a 911 call [e.g., "He's here jumpin' on me again."] were nontestimonial:

The statements in Davis were taken when McCottry was alone, not only unprotected by police, but apparently in immediate danger from Davis. She was seeking aid, not telling a story about the past. McCottry's present-tense statements showed immediacy.

In Davis, McCottry was speaking about events as they were actually happening, rather than "describ[ing] past events." *** Moreover, any reasonable listener would recognize that McCottry ... was facing an ongoing emergency. Although one might call 911 to provide a narrative report of a crime absent any imminent danger, McCottry's call was plainly a call for help against bona fide physical threat. Third, the nature of what was asked and answered in Davis, again viewed objectively, was such that the elicited statements were necessary to be able to resolve the present emergency, rather than simply to learn (as in Crawford) what had happened in the past. That is true even of the operator's effort to establish the identity of the assailant, so that the dispatched officers might know whether they would be encountering a violent felon. And finally, the difference in the level of formality between the two interviews is striking. Crawford[' $s$ wife] was responding calmly, at the station house, to a series of questions, with the officer-interrogator taping and making notes of her answers: McCottry's frantic answers were provided over the phone, in an environment that was not tranquil, or even (as far as any reasonable 911 operator could make out) safe.

We conclude from all this that the circumstances of McCottry's interrogation objectively indicate its primary purpose was to enable police assistance to meet an ongoing emergency. She simply was not acting as a witness; she was not testifying. $* * *$

This is not to say that a conversation which begins as an interrogation to determine the need for emergency assistance cannot, as the Indiana Supreme Court put it, "evolve into testimonial statements," once that 
purpose has been achieved. In this case, for example, after the operator gained the information needed to address the exigency of the moment, the emergency appears to have ended (when Davis drove away from the premises). The operator then told McCottry to be quiet, and proceeded to pose a battery of questions. It could readily be maintained that, from that point on, McCottry's statements were testimonial, not unlike the "structured police questioning" that occurred in Crawford. This presents no great problem. Just as, for Fifth Amendment purposes, "police officers can and will distinguish almost instinctively between questions necessary to secure their own safety or the safety of the public and questions designed solely to elicit testimonial evidence from a suspect," trial courts will recognize the point at which, for Sixth Amendment purposes, statements in response to interrogations become testimonial. Through in limine procedure, they should redact or exclude the portions of any statement that have become testimonial, as they do, for example, with unduly prejudicial portions of otherwise admissible evidence.

On the other hand, it held that in the companion case of Hammon $v$. Indiana, the domestic violence victim's (1) oral statements to the responding police, in answer to their questions and (2) her affidavit signed at the scene were both testimonial. Justice Scalia analyzed the statements to the responding police as follows:

It is entirely clear from the circumstances [in Hammon] that the interrogation was part of an investigation into possibly criminal past conduct - as, indeed, the testifying officer expressly acknowledged. There was no emergency in progress; the interrogating officer testified that he had heard no arguments or crashing and saw no one throw or break anything. When the officers first arrived, Amy told them that things were fine, and there was no immediate threat to her person. When the officer questioned Amy for the second time, and elicited the challenged statements, he was not seeking to determine (as in Davis) "what is happening," but rather "what happened." Objectively viewed, the primary, if not indeed the sole, purpose of the interrogation was to investigate a possible crime. ...

2 Justice Thomas roundly criticized the Court for failing to provide a workable standard for distinguishing between testimonial and nontestimonial statements:

In many, if not most, cases where police respond to a report of a crime, whether pursuant to a 911 call from the victim or otherwise, the purposes of an interrogation, viewed from the perspective of the police, are both to respond to the emergency situation and to gather evidence. See New York v. Quarles, 467 U.S. 649, 656 (1984) ("Undoubtedly most police officers [deciding whether to give Miranda warnings in a possible emergency situation] would act out of a host of different, instinctive, and largely unverifiable motives - their own safety, the safety of others, and perhaps as well the desire to obtain incriminating evidence from the suspect"). Assigning one of these two "largely unverifiable motives," primacy requires constructing a hierarchy of purpose that will 
*** It was formal enough that Amy's interrogation was conducted in a separate room, away from her husband (who tried to intervene), with the officer receiving her replies for use in his "investigat[ion]." *** Both declarants [Hammon's wife, Amy, and Crawford's wife, Sylvia] were actively separated from the defendant -officers forcibly prevented Hershel from participating in the interrogation. Both statements deliberately recounted, in response to police questioning, how potentially criminal past events began and progressed. And both took place some time after the events described were over. Such statements under official interrogation are an obvious substitute for live testimony, because they do precisely what a witness does on direct examination; they are inherently testimonial.

*** Amy's narrative of past events was delivered at some remove in time from the danger she described. And after Amy answered the officers' questions, he had her execute an affidavit, in order, he testified, "[t]o establish events that have occurred previously."

The resulting erosion of the utility for the prosecution of the excited utterance hearsay exception had been foreshadowed by Justice Scalia's comments in footnote 8 of Crawford, regarding White v. Illinois.

rarely be present-and is not reliably discernible. It will inevitably be, quite simply, an exercise in fiction. $* *$ [T] he fact that the officer in Hammon was investigating $\mathrm{Mr}$. Hammon's past conduct does not foreclose the possibility that the primary purpose of his inquiry was to assess whether Mr. Hammon constituted a continuing danger to his wife, requiring further police presence or action. It is hardly remarkable that Hammon did not act abusively towards his wife in the presence of the officers, and his good judgment to refrain from criminal behavior in the presence of police sheds little, if any, light on whether his violence would have resumed had the police left without further questioning, transforming what the Court dismisses as "past conduct" back into an "ongoing emergency."

Davis v. Washington, 126 S.Ct. 2266, 2283-85 (U.S. 2006) (Thomas, J., concurring in judgment in part and dissenting in part). 
In extending "testimonial" to responses to at least some responses to initial police inquiries in the field, "the Davis court went beyond "formalized testimony or its equivalent" and thus lost the vote of Justice Thomas.

\section{§ 7. How Can We Analyze Whether Statements Outside the Holdings of Crawford and Davis are Testimonial?}

We must look at the Court's rationales in Crawford and Davis and the clues in dicta in Crawford and extrapolate from them in order to predict the outcome in future cases. What happens, for example, when the declarant's statement is not made to an agent of law enforcement? In footnote 2 in Davis, the Court makes clear that it is not addressing that question, as it says:

If 911 operators are not themselves law enforcement officers, they may at least be agents of law enforcement when they conduct interrogations of 911 callers. For purposes of this opinion (and without deciding the point), we consider their acts to be acts of the police. As in Crawford $v$. Washington, therefore, our holding today makes it unnecessary to consider whether and when statements made to someone other than law enforcement personnel are "testimonial."

This last comment - coupled with Davis' reliance on the differing formality of the Davis and Hammon statements - supports an argument that the Court is adopting some version of one or two of the following formulations it had quoted but declined to explicitly adopt in Crawford:

Various formulations of this core class of "testimonial" statements exist: "ex parte in-court testimony or its functional equivalent - that is, material such as affidavits, custodial examinations, prior testimony that the defendant was unable to cross-examine, or similar pretrial statements that declarants would reasonably expect to be used prosecutorially," Brief for Petitioner 23; * ** "statements that were made under circumstances which would lead an

${ }^{3}$ The Davis court explained:

Although we necessarily reject the Indiana Supreme Court's implication that virtually any "initial inquiries" at the crime scene will not be testimonial, we do not hold the opposite - that no questions at the scene will yield nontestimonial answers. We have already observed of domestic disputes that "[o]fficers called to investigate ... need to know whom they are dealing with in order to assess the situation, the threat to their own safety, and possible danger to the potential victim." Hiibel, 542 U.S. at 186, 124 S.Ct. 2451 . Such exigencies may often mean that "initial inquiries" produce nontestimonial statements. But in cases like this one, where Amy's statements were neither a cry for help nor the provision of information enabling officers immediately to end a threatening situation, the fact that they were given at an alleged crime scene and were "initial inquiries" is immaterial. 
objective witness reasonably to believe that the statement would be available for use at a later trial," Brief for National Association of Criminal Defense Lawyers et al, as Amici Curiae 3. *** Regardless of the precise articulation , some statements [like Mrs. Crawford's statement to police at the station house] qualify under any definition.

Justice Scalia's opinion in Crawford suggests that several categories of hearsay are nontestimonial:

"[N]ot all hearsay implicates the Sixth Amendment's core concerns. An off-hand, overheard remark bears little resemblance to the civil-law abuses the Confrontation Clause targeted. *** An accuser who makes a formal statement to government officers bears testimony in a sense that a person who makes a casual remark to an acquaintance does not."

"Most of the hearsay exceptions [that had become well established by 1791] covered statements that by their nature were not testimonial-for example, business records or statements in furtherance of a conspiracy."

"Even our recent cases, in their outcomes, hew closely to the traditional line. *** Bourjaily v. United States, 483 U.S. 171, 181-184, 107 S.Ct. 2775, 97 L.Ed.2d 144 (1987), admitted statements made unwittingly to an FBI informant. ..." [Justice Scalia's selection of the fact that the declarant did not know he was speaking to a government agent, but did so "unwittingly," suggests that he believes that that fact makes the declarant's statement nontestimonial - even though, undoubtedly, the FBI informant's (the hearer's) intent was to gather evidence for the government.]

In Davis, Justice Scalia reiterates that, "even when interrogation exists, it is in the final analysis the declarant's statements, not the interrogator's questions, that the Confrontation Clause requires us to evaluate." See United States v. Brito, 427 F.2d 53, 61-62 (1st Cir. 2005), cert. denied, 126 S.Ct. 2983 (2006) ("Ordinarily, statements made to police while the declarant or others are still in personal danger cannot be said to have been made with consideration of their legal ramifications. Such a declarant usually speaks out of urgency and a desire to obtain a prompt response.").

Footnote 6 in Crawford suggests that even testimonial dying declarations may not be excluded by the confrontation clause, because they were admissible under the common law of 1751. 


\section{§ 8. How Did the Maryland Court of Appeals Interpret Crawford in Snowden?}

In its first post-Crawford decision, Snowden v. State, the Court of Appeals of Maryland held that 8 and 10-year-old girls' statements during an interview with a social worker were testimonial, under the following facts:

- The social worker was a county employee who described her position as a "sexual abuse investigator';

- She interviewed the children with a police detective present in the room;

- The express purpose of the interviews "was to develop their testimony for possible use at trial";

- Each child told her that "she was aware that she was being interviewed as a result of her accusations against [the defendant]";

- The children were interviewed "at a County-owned and operated facility unfamiliar to the children and used for the purpose of investigating and assessing victims of child abuse."

Judge Harrell emphasized:

Most telling [was] the fact that [social worker] Wakeel's participation in this matter was initiated, and conducted, as part of a formal law enforcement investigation. The children were interviewed at the behest of Detective Davey of the Montgomery County Police Department, who was actively involved in the investigation. Unlike some cases in which statements to investigators were deemed nontestimonial because they were in the course of ascertaining whether a crime had been committed, the children's statements were elicited by Wakeel subsequent to initial questioning of them by the police and after the identity of a suspect was known. Indeed, Wakeel testified that she began her investigation with a police report in hand, which stated that "Michael Snowden had sexually abused these children."

In this context, the court was satisfied that the social worker was acting as "an agent of the police department."

The Snowden court added this caveat:

Statements made to a school principal conducting a casual chat with a student, for example, do not present necessarily the same potential constitutional abuses as when a child's statement is made to a health or social work professional that is working in 


\section{tandem with law enforcement in furtherance of an ongoing and formal criminal}

investigation. We leave to another day the question of whether such noninvestigatory statements would be admissible in light of Crawford.

The court rejected the notion, however, that the analysis should consider the young age of the declarant.

The Supreme Court's resolution of the facts before it in Davis v. Washington is consistent with the Court of Appeals of Maryland's earlier decision in Snowden. The social worker in Snowden - like the 911 operator in Davis - was held to be acting as an agent of the police, and the children's statements to her were made when there was no ongoing emergency or criminal activity and the children were safe. The Snowden court, like Davis, applied an objective rather than a subjective test.

\section{§ 9. What About "Business Records" of the State?}

In Rollins v. State, the Court of Appeals affirmed a Court of Special Appeals' decision that "the findings in an autopsy report of the physical condition of a decedent, which are routine, descriptive and not analytical, [and] which are objectively ascertained" were non-testimonial. The medical examiner-declarant had moved to California and did not testify, but his deputy medical examiner testified, basing her testimony on the autopsy report. The trial court had redacted some of the original medical examiner's opinions regarding "disease ... [,] smothering ... [and] homicide ... by asphyxiation." In an opinion by Judge Greene, a unanimous Court of Appeals held:

[T] he autopsy report, as redacted, contained non-testimonial hearsay statements in nature that were admissible under either the business or public records exceptions to the hearsay rule. We further hold that, under the facts of the instant case, the availability of a witness is immaterial to the question of admissibility of hearsay evidence under either the business or public records exception. Opinions, speculation, and other conclusions drawn from the objective findings in autopsy reports are testimonial and should be redacted before the report is admitted into evidence.

The information that was not redacted from the autopsy report, while it might eventually be used in a criminal trial, was not created for that express purpose, and was statutorily required to be determined by the medical examiner and placed into the report pursuant to $\S 5-311$ of the Health General Article.

In contrast to Rollins, see United States v. Feliz, 467 F.3d 223 (2d Cir. 2001) (finding autopsy reports to be nontestimonial business records and public records and affirming conviction, when only a doctor from the medical examiner's office who had not conducted the autopsies testified at trial as to the autopsies). 
With a focus on the routine nature of the statement, the United States Court of Appeals for the Ninth Circuit has held that public records contained in the accused's "penitentiary packet" - records of his convictions, his fingerprints and a photograph - were not testimonial. Moreover, their certification as accurate copies of those public records, by the Oklahoma records custodian and by Oklahoma's Secretary of State, were also routine, non-testimonial statements, United States v. Weiland, 420 F.3d 1062, 1076-77 (9th Cir. 2005), cert. denied, 126 S.Ct. 1911 (U.S. 2006).

\section{§ 10. Dying Declarations}

In its first post-Davis decision, the Court of Special Appeals relied on Davis to conclude that a dying declaration was nontestimonial. In Head v. State, $171 \mathrm{Md}$. App. 642, 912 A.2d 1 (2006), cert. denied, $395 \mathrm{Md}$. 315, 920 A.2d 1059 (2007), the first police officer arriving at the scene of a shooting asked the victim, "Who shot you?" The victim, who died within the hour, answered "Bobby."

Judge Salmon, writing for the panel in a manner reminiscent of Louis L'Amour, pointed out "the strong smell of gunpowder still in the air." That fact, coupled with the officer's testimony that the victim "kept 'yelling out' the words "help me, help me,", "the situation was "chaotic," the officer " didn't even know if . .. the person who caused that gunpowder was still in the house," and "in the officer's view, it was still 'potentially even a dangerous situation... ," led the panel to conclude that the statement was nontestimonial under Davis, because, "Viewed objectively, the primary purpose of Officer George's question does not appear to have been either to establish or prove past events for possible use at a trial."

\section{§ 11. How Are Prosecutors and Domestic Violence Victim-Advocates Likely to Adapt to these Changes?}

Crawford and Davis require strategic changes by the prosecution.

a. Whereas before Crawford and Davis a case might have been prosecuted through the admission of excited utterances to police, Crawford and Davis increase the incentives to do everything possible to have the declarant testify at trial and thus be subject to cross-examination by the accused.

\section{Practical problems:}

Sometimes it is not in the state's power to have the declarant testify:

(1) Child abuse victims who are very young may be found to be unqualified to testify in court;

(2) Domestic violence victims may invoke a marital privilege not to testify, or 
Witnesses of any kind may be afraid to testify, for fear of retaliation.

b. The prosecution may begin to, more routinely, conduct a prompt preliminary hearing at which the defense has the opportunity to cross-examine. Then, if the declarant subsequently becomes unavailable, Crawford is satisfied.

c. If it believes that the witness's unavailability to testify has been caused by the accused's intimidation or other wrongdoing (such as threats, bribery, assault, or murder) then the prosecution will follow the Court's suggestions in Crawford and Davis to pursue a ruling that the accused has forfeited his or her right to confront the witness. See $\S 11$.

\section{$\S 12$. Forfeiture of Right to Object}

As Justice Scalia explained in Davis:

Domestic violence . . . . is notoriously susceptible to intimidation or coercion of the victim to ensure that she does not testify at trial. When this occurs, the Confrontation Clause gives the criminal a windfall. We may not, however, vitiate constitutional guarantees when they have the effect of allowing the guilty to go free. But when defendants seek to undermine the judicial process by procuring or coercing silence from witnesses and victims, the Sixth Amendment does not require courts to acquiesce. While defendants have no duty to assist the State in proving their guilt, they do have the duty to refrain from acting in ways that destroy the integrity of the criminal-trial system. We reiterate what we said in Crawford: that "the rule of forfeiture by wrongdoing (which we accept) extinguishes confrontation claims on essentially equitable grounds " (citing Reynolds, 98 U.S. at 158-159). That is, one who obtains the absence of a witness by wrongdoing forfeits the constitutional right to confrontation.

We take no position on the standards necessary to demonstrate such forfeiture, but federal courts using Federal Rule of Evidence 804(b)(6), which codifies the forfeiture doctrine, have generally held the Government to the preponderance-ofthe-evidence standard, see, e.g., United States v. Scott, 284 F.3d 758, 762 (C.A.7 2002). State courts tend to follow the same practice, see e.g., Commonwealth $v$. Edwards, 444 Mass. 526, 542, 830 N.E.2d 158, 172 (2005). Moreover, if a hearing on forfeiture is required, $E d w a r d s$, for instance, observed that "hearsay evidence, including the unavailable witness's out-of-court statements, may be considered." ***

We have determined that, absent a finding of forfeiture by wrongdoing, the Sixth Amendment operates to exclude Amy Hammon's affidavit. The Indiana courts 
may (if they are asked) determine on remand whether such a claim of forfeiture is properly raised and, if so, whether it is meritorious.

The Maryland forfeiture statute is considerably narrower than either the common law constitutional principle or Fed. R. Evid 804(b)(6). Md. Cts. \& Jud. Proc. Code Ann. $\$ 10-901$ provides:

(a) During the trial of a criminal case in which the defendant is charged with a felonious violation of Title 5 of the Criminal Law Article or with the commission of a crime of violence as defined in 14-101 of the Criminal Law Article, a statement as defined in Maryland Rule 5-801(a) is not excluded by the hearsay rule if the statement is offered against a party that has engaged in, directed, or conspired to commit wrongdoing that was intended to and did procure the unavailability of the declarant of the statement, as defined in Maryland Rule 5804.

(b) Subject to subsection (c) of this section, before admitting a statement under this section, the court shall hold a hearing outside the presence of the jury at which:

(1) The Maryland Rules of Evidence are strictly applied; and

(2) The court finds by clear and convincing evidence that the party against whom the statement is offered engaged in, directed, or conspired to commit the wrongdoing that procured the unavailability of the declarant,

(c) A statement may not be admitted under this section unless:

(1) The statement was:

(i) Given under oath subject to the penalty of perjury at a trial, hearing, or other proceeding or in a deposition;

(ii) Reduced to writing and signed by the declarant; or

(iii) Recorded in substantially verbatim fashion by stenographic or electronic means contemporaneously with the making of the statement; and

(2) As soon as is practicable after the proponent of the statement learns that the declarant will be unavailable, the proponent notifies the adverse party of:

(i) The intention to offer the statement;

(ii) The particulars of the statement; and 
(iii) The identity of the witness through whom the statement will be offered.

First, unlike the federal rule, the Maryland statute is restricted so as to apply only to trials for certain crimes: those involving either drug distribution ("felonious violations of Title 5 of the Criminal Law Article") or those that qualify as "crimes of violence as defined in 14-101 of the Criminal Law Article." The latter category does not include second degree assault (which is often charged in domestic violence cases). In the 2006 session $\$ 14-101$ of the Criminal Law article was amended to include "child abuse in the first degree under \$3-601 of [the Criminal Law] article" as a "crime of violence." In 2007 the General Assembly added "sexual abuse of a minor under $\S 3-602$ of [the Criminal law] article if: (i) the victim is under the age of 13 years and the offender is an adult at the time of the offense; and (ii) the offense involved: (1) vaginal intercourse, as defined in § 3-301 of this article; (2) a sexual act, as defined in $\S 3-301$ of this article; (3) an act in which a part of the offender's body penetrates, however slightly, into the victim's genital opening or anus; or (4) the intentional touching, not through the clothing, of the victim's or the offender's genital, anal, or other intimate area for sexual arousal, gratification, or abuse" and "continuing course of conduct with a child under $\S 3-315$ of the Criminal Law article."

Second, the statute is intended to provide that unlike in other preliminary determinations by the trial judge (outside the hearing of the jury) as to admissibility of evidence under Md. Rule 5-104(a), the other Maryland Rules of evidence (including the hearsay rule) will be "strictly applied" at this preliminary stage. The preliminary facts must be proved either by the testimony of another witness who has first-hand knowledge of them, or by the unavailable witness's out-of-court statements that qualify under a hearsay exception, such as that for excited utterances.

Third, the statute applies a burden of "clear and convincing evidence" at this stage, unlike the ordinary burden of a preponderance of the evidence. This is a departure from the Maryland case law which has applied the clear and convincing standard only when evidence of an accused's "other crimes" is to be admitted before the jury, the trier of fact. Under the forfeiture doctrine, the jury does not hear of the party's wrongdoing that made the witness unavailable, but only of the unavailable declarant's out-of-court statement, which is directly relevant to the pending charge. (It should be noted that evidence of that wrongdoing might come in under a preexisting, independent route, such as that of wrongful acts showing "guilty knowledge.")

The Md. Rule applicable in civil cases, new Md. Rule 5-804(b)(5), which became effective January 1, 2006, provides:

(b) Hearsay Exceptions. The following are not excluded by the hearsay rule if the declarant is unavailable as a witness: 


\section{(5) Witness Unavailable Because of Party's Wrongdoing}

(A) Civil Actions. In civil actions in which a witness is unavailable because of a party's wrongdoing, a statement that (i) was (a) given under oath subject to the penalty of perjury at a trial, hearing, or other proceeding or in a deposition; (b) reduced to writing and was signed by the declarant; or (c) recorded in substantially verbatim fashion by stenographic or electronic means contemporaneously with the making of the statement, and (ii) is offered against a party who has engaged in, directed, or conspired to commit wrongdoing that was intended to, and did, procure the unavailability of the declarant as a witness, provided however, the statement may not be admitted unless, as soon as practicable after the proponent of the statement learns that the declarant will be unavailable, the proponent makes known to the adverse party the intention to offer the statement and the particulars of it.

(B) Criminal Causes. In criminal causes in which a witness is unavailable because of a party's wrongdoing, admission of the witness's statement under this exception is governed by Code, Courts Article, $\S 10-901$.

The accompanying Committee note explains that "A 'party' referred to in subsection (b)(5)(A) also includes an agent of the government." It adds:

Subsection (b)(5) of this Rule does not affect the law of spoliation, 'guilty knowledge,' or unexplained failure to produce a witness to whom one has superior access. See Washington v. State, 293 Md. 465, 468 n.1 (1982); Breeding v. State, 220 Md. 193, 197 (1959); Shpak v. Schertle, 97 Md. App. 207, 222-27 (1993); Meyer v. McDonnell, $40 \mathrm{Md}$. App. 524, 533 (1978), rev'd on other grounds, 301 Md. 426 (1984); Larsen v. Romeo, 254 Md. 220, 228 91969); Hoverter v. Director of Patuxent Inst., 231 Md. 608, 609 (1963); and DiLeo v. Nugent, 88 Md. App. 59, 69-72 (1991).

The statute and the Rule share three differences from the federal rule:

(1) The types of statements potentially admissible are narrowed to only those types that also are potentially substantively admissible prior inconsistent statements under Md. Rule 5-802.1 (a) (but under that rule, of course, the declarant must testify at trial). Thus, neither the statute nor the Rules Committee's pending proposal would give the courts leeway to consider possibly admitting statements made by those witnesses who were murdered preemptively or intimidated before their statements were recorded or signed.

(2) The proponent of the evidence must provide notice of its intent to offer evidence under this hearsay exception. 
(3) Rather than adopting the federal rule's language of "engaged or acquiesced in," the party against whom the evidence is offered must be shown to have "engaged in, directed, or conspired to commit the wrongdoing that procured the unavailability of the declarant." This language is thought to be clearer.

If the judge decides to admit proof of the hearsay statement, then any witness who testifies to it will be subject to full cross-examination and impeachment before the jury. The unavailable hearsay declarant, too, will be subject to impeachment. See Md. Rule 5-806.

The common law constitutional forfeiture doctrine is considerably broader than either Fed. R. Evid. 804(b)(6), or the Maryland laws. The common law has been applied by various state and federal courts whenever the opposing party's wrongdoing has been preliminarily found by the trial court, by a preponderance of the evidence (under Rule 104(a), so that the rules of evidence do not apply at this stage), to have caused the unavailability of the declarant - regardless whether that party was shown to have intended to prevent the declarant from testifying. E.g., United States v. Garcia-Meza, 403 F..3d 364 (6th Cir. 2005).

\section{§ 13. Hypotheticals}

Under Crawford and Davis, are the following statements testimonial?

a. A domestic violence victim's excited utterance to a police officer who arrives at her door? If she is saying, "He's got a gun!"

b. A 911 call by a witness to a stabbing? If he is seeking an ambulance? If he is seeking police assistance?

c. A police lab technician's report on a defendant's blood alcohol level? The DNA of blood found at a crime scene?

d. A hospital report as to blood analysis of a "regular" patient? Of a patient brought in by police for DUI?

e. (i) If a neighbor asks to have a 7-year-old child come over "to help around the house" and the child tells his mother, 'I don't want to go! He did something bad to me last time," is the child's statement testimonial?

(ii) If the mother calls Social Services and takes the child in for an interview because of suspected child abuse, are the child's statements to the social worker testimonial? Does it matter whether a police officer is present during the interview? If the officer is in plain clothes and the child does not know that s/he is an officer? 
(iii) Would it matter if the social worker was employed by a private agency or a church, rather than the local government?

(iv) If the mother instead takes the child to the hospital, are the child's statements to the doctor and nurses - describing the abuse and identifying the abuser - testimonial? Of what import is it that all Maryland citizens have a duty to report child abuse? See Griner v. State, 168 Md. App. 714, 899 A.2d 189, 20108 (2006).

(v) Does it matter whether the child is 3 , or 7 , or 12 ?

f. Is a mentally disabled victim who is called by the prosecution - to demonstrate her limited mental capacity, rather than to testify to the alleged crime against her a witness under the Sixth Amendment? (P.G. County trial, Feb. 2006).

g. With regard to whether a domestic violence victim's statement is testimonial, is it significant that many/most DV victims do not cooperate with the prosecution at trial? Would they cooperate long enough to have a preliminary hearing?

h. Is pleading with a domestic violence victim not to testify "wrongdoing"? Can one get a "no contact" order pending trial?

i. Is a letter, "to be opened in the event of my death," testimonial?

j. What about a statement of fear to a friend, "I'm afraid my husband is going to kill me one of these days"? Testimonial or not? 